\title{
Metastasis of prostate carcinoma to the thyroid cartilage presenting with airway obstruction
}

\author{
Jack Gao (1) , Tharsika Myuran, Madhup Chaurasia
}

Ear, Nose and Throat Department, Mid and South Essex Hospital Services NHS Trust, Chelmsford, Essex, UK

\section{Correspondence to} Dr Jack Gao; jack7.gao7@gmail.com

Accepted 2 February 2021

\section{DESCRIPTION}

It is generally presumed that large neck masses resulting in airway obstruction are associated with a primary neoplastic problem in the upper aero-digestive tract mucosa, usually a carcinoma. Metastasis into the neck from regions below the diaphragm, such as the prostate, though not unknown, is very rare. We present a case of airway obstruction due to metastatic prostate carcinoma within the thyroid cartilage.

A 66-year-old man with a background of metastatic prostate carcinoma and enlarging left neck lump (level 2-3) for 8 months presented to us with airway compromise and required an urgent tracheostomy.

A recent MRI demonstrated a left-sided mass arising from the thyroid cartilage, crossing the midline and encroaching towards the larynx with considerable airway compromise. There was complete destruction of the left lobe and lower pole of the right lobe of the thyroid gland with enlarged cervical lymph nodes at level II and III on the left (figures 1 and 2).

Under strict vigilance in the operating theatre and precautionary plans, the patient was successfully intubated before tracheostomy and biopsy of the mass through the tracheostomy incision. Rigid laryngoscopy showed medialisation of laryngeal structures on the left with mild false cord oedema but no laryngeal mass.

Histological examination of the biopsy showed fibrocollagenous tissue infiltrated by sheets of highly atypical cells with neuroendocrine features.

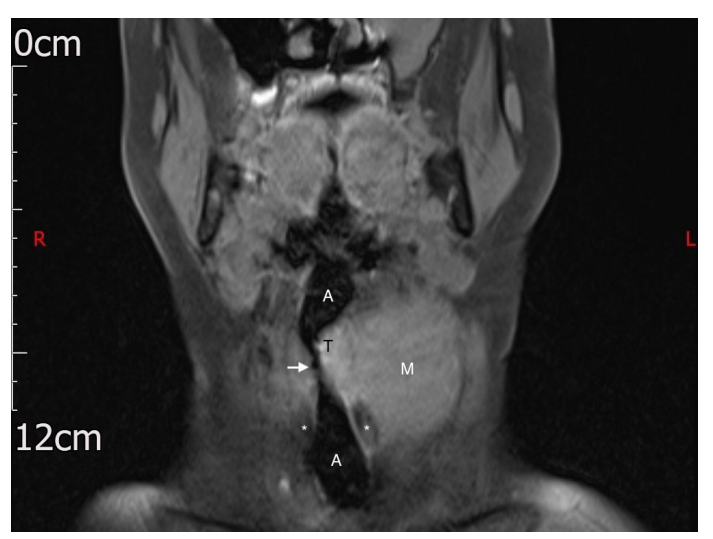

Figure 1 MRI of the neck (T1-weighted)—coronal slice demonstrating a large, lobulated, heterogeneously enhancing, left-sided, $7 \times 5.1 \times 5.3 \mathrm{~cm}$ neck mass arising from the thyroid cartilage and crossed the midline. Arrow indicates narrowest point of airway. A, airway; L, left; $M$, mass; $R$, right; $T$, thyroid cartilage; ${ }^{*}$ cricoid cartilage.

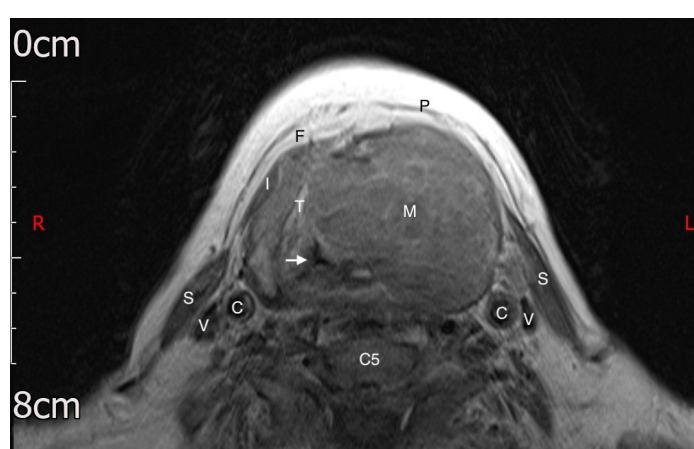

Figure 2 MRI of the neck (T1-weighted)—axial slice at level of thyroid cartilage and $\mathrm{C} 5$ cervical vertebra demonstrating large, left-sided neck mass compressing the airway. Arrow indicates narrowest point of airway. C, common carotid arteries; $C 5$, vertebral body of fifth cervical vertebra; $F$, investing layer of deep cervical fascia; I, infrahyoid (STRAP) muscles; L, left; M, mass; P, platysma muscle; $R$, right; $S$, sternocleidomastoid muscles; $T$, thyroid cartilage; $V$, internal jugular veins.

Tumour cells showed positivity for PSA (prostatespecific antigen), PSAP (prostatic specific acid phosphatase), CD56, chromogranin and TTF-1 (thyroid transcription factor 1). The findings were consistent with those of metastatic prostatic carcinoma with neuroendocrine differentiation, similar to the previous histological findings from the prostate.

A multidisciplinary decision was made for palliative treatment due to the extent of disease metastasis.

Distant metastases of cancers are thought to occur via the blood or lymphatic vessels and, as these are sparse within the hyaline thyroid cartilage, prostate cancer metastases to the thyroid cartilage are considered very rare. Indeed, a literature search has revealed only six other reported cases of prostate carcinoma with thyroid cartilage metastasis. ${ }^{1-6}$

Despite this, a histopathological study has found microscopic metastases to the thyroid cartilage in five out of six postmortem patients with advanced prostate carcinoma, suggesting that distant metastases to cartilage may be more prevalent than previously thought. ${ }^{7}$ Potential explanations may lie within the haematogenous or lymphatic routes of distant cancer metastases.

First, hyaline cartilage is known to undergo bony metaplasia and ossification during the ageing process and, as bone has a better vascular supply than cartilage, it has already been hypothesised that this phenomenon could explain a distant metastasis through the haematogenous route. ${ }^{8}$ 
Furthermore, a recent study has shown that expression of noncaveolar Cav-1 by prostatic carcinoma cells in particular favours lymphangiogenesis. This lymphatic endothelial cell proliferation is mediated by the panangiogenesis regulator, vascular endothelial growth factor-A. A high predilection for lymphatic metastasis can be an early feature of disease progression in prostatic cancer, providing another potential explanation for a very distant metastasis, as seen in this case. ${ }^{9}$

\section{Learning points}

- Securing the airway takes priority over other diagnostic tests.

- When performing emergency tracheostomy for airway obstruction, where malignancy is highly suspected, consider also performing rigid pharyngoscopy, laryngoscopy or oesophagoscopy and biopsy if time, expertise and facilities permit.

- Maintain a wide list of differential diagnoses. A lump in the neck may have metastasised from regions not necessarily above the diaphragm (eg, prostate carcinoma with neck metastasis).

Acknowledgements We would like to thank Nicola Brown from the imaging office for assisting in acquiring and formatting the images.

Contributors Author JG played a role in idea conception for the paper, planning, conducting case report, interpreting images, gaining patient consent, acquiring images for publication, drafting the paper, literature search, giving approval for publication and agrees to be accountable for the contents of the paper. Author TM played a role in idea conception for the paper, planning, conducting case report, interpreting images, drafting the paper, literature search, giving approval for publication and agrees to be accountable for the contents of the paper. Senior author MC played a role in idea conception for the paper, planning, conducting case report, interpreting images, drafting the paper, literature search, giving approval for publication and agrees to be accountable for the contents of the paper. All three authors were involved in the management of the patient.

Funding The authors have not declared a specific grant for this research from any funding agency in the public, commercial or not-for-profit sectors.

Competing interests None declared.

Patient consent for publication Obtained.

Provenance and peer review Not commissioned; externally peer reviewed.

ORCID iD

Jack Gao http://orcid.org/0000-0001-9391-6373

\section{REFERENCES}

1 Park YW, Park MH. Vocal cord paralysis from prostatic carcinoma metastasizing to the larynx. Head Neck 1993;15:455-8.

2 Annovazzi A, Faiella A, Pescarmona E, et al. Asymptomatic metastasis to thyroid cartilage detected by 18F-choline and 64CU-PSMA PET/CT as a single site of disease relapse in a patient with castration-resistant prostate carcinoma. Clin Nucl Med 2020:45:214-6.

3 Escudero RM, Amo FH, Martínez MCN, et al. Metastatic prostate cancer on the thyroid cartilage: unusual symptoms of prostatic adenocarcinoma. Case report. Arch Esp Urol 2011;64:132-5.

4 Quinn FB, McCabe BF. Laryngeal metastases from malignant tumors in distant organs. Ann Otol Rhinol Laryngol 1957;66:139-43.

5 Hessan H, Strauss M, Sharkey FE. Urogenital tract carcinoma metastatic to the head and neck. Laryngoscope 1986;96:1352-6.

6 Nohara T, Kawashima A, Takahashi T, et al. [Prostate cancer metastasized to thyroid cartilage: a case report]. Nihon Hinyokika Gakkai Zasshi 2005;96:697-700.

7 Prescher A, Schick B, Stütz A, et al. Laryngeal prostatic cancer metastases: an underestimated route of metastases? Laryngoscope 2002;112:1467-73.

8 EHRLICH A. Tumor involving the laryngeal cartilages. AMA Arch Otolaryngol 1954;59:178-85.

9 Nassar ZD, Hill MM, Parton RG, et al. Non-Caveolar caveolin-1 expression in prostate cancer cells promotes lymphangiogenesis. Oncoscience 2015;2:635-45.

Copyright 2021 BMJ Publishing Group. All rights reserved. For permission to reuse any of this content visit

https://www.bmj.com/company/products-services/rights-and-licensing/permissions/

BMJ Case Report Fellows may re-use this article for personal use and teaching without any further permission.

Become a Fellow of BMJ Case Reports today and you can:

- Submit as many cases as you like

- Enjoy fast sympathetic peer review and rapid publication of accepted articles

- Access all the published articles

Re-use any of the published material for personal use and teaching without further permission

\section{Customer Service}

If you have any further queries about your subscription, please contact our customer services team on +44 (0) 2071111105 or via email at support@bmj.com.

Visit casereports.bmj.com for more articles like this and to become a Fellow 